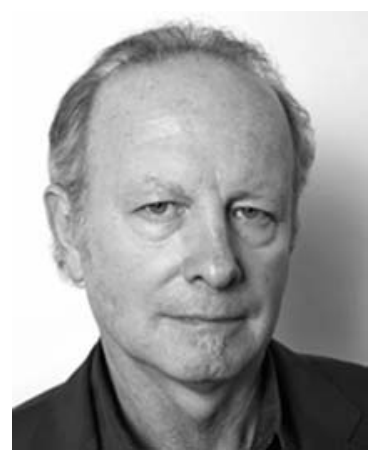

\title{
A Conversation with Joseph LeDoux
}

\author{
INTERVIEWER: CHARVy NARAIN
}

\section{Former Senior Editor, Nature Neuroscience}

Dr. LeDoux is the Henry and Lucy Moses Professor of Science at NYU in the Center for Neural Science, and he directs the Emotional Brain Institute of NYU and the Nathan Kline Institute. He is also a Professor of Psychiatry and Child and Adolescent Psychiatry at NYU Langone Medical School.

Charvy Narain: You are going to talk about a sort of a new twist in the very old topic on fear and how it works in the amygdala.

Dr. LeDoux: Right. I've been working on fear for roughly 30 years, and after all that time, I decided I hadn't been working on fear at all. It may seem odd, but if you look back over the way I've talked about fear all these years, the idea has been in there the whole time. Basically, I think what we study when we study animals, and also often when we're studying humans, is the processes in the brain that detect and respond to danger. Fear is something additional.

It's the ability of the conscious brain to apprehend that the stuff under the hood has detected and responded to danger and to be aware of all of the consequences that threat detection produces in the brain and in the body, and all of the feedback and all of the other stuff that's going on. It's not just body feedback, but also information from within the brain itself like arousal.

I no longer talk about Pavlovian fear conditioning. I talk about Pavlovian threat conditioning because it's really about how the stimulus has changed in the brain and how that change allows that stimulus now to produce defense responses.

Fear is something we can know and study and talk about in people, but we have no idea what another animal is experiencing, so the language I am proposing is a way to avoid conflation of conscious fear with these threat detection and response mechanisms.

For example, people go to a therapist and seek treatment because they feel bad. They have conscious sensations and feelings that they don't want to have. Those are being influenced but not directly caused by systems underneath. We shouldn't mix those two things up (the nonconscious and conscious), since they might be treatable in different ways.

Charvy Narain: Are you saying that there's threat detection, which is separate, and there's the cognitive sort of stuff which goes with threat detection which deserves the label fear?

Dr. LeDoux: That's pretty close to it, yes. Cognitive behavioral therapy is a common approach, and that approach mixes two things together that need to be separated. Though this therapy is often equated with extinction, it's really much more than stimulus exposure. I think that the cognitive support and stimulus exposure parts need to be separated. I got through this argument in my new book, Anxious, but that's not what I'm going to talk about tonight, so maybe I should kind of switch gears.

Charvy Narain: What made you sort of realize that there's this difference? After 30 years of work, what ends up changed?

Dr. LeDoux: It's just been gnawing away at me, kind of like an almost imperceptible itch that I've been wanting to scratch, because I've always said that the conscious feeling of fear is something that involves attention and working memory and all kinds of cognitive processes, but the mistake I made was calling what the amygdala does the fear system. I'm guilty in this mess as well.

Charvy Narain: In that sense almost everybody is.

Dr. LeDoux: I think we're at a point where we've made a lot of progress and a sharper conception of what we're really studying and talking about would help the field advance to the next level.

Charvy Narain: What sort of implications do you think this has for animal models of fear, because you're talking about fear as the sort of conscious perception?

Dr. LeDoux: I would no longer call them animal models of fear. I would call a spade a spade and say that while animal research is very, relevant to human fear and anxiety, when we do so-called fear conditioning we are not 
studying those processes that people feel and experience. We do want to understand how those things are happening because they're fundamental to those experiences, but they have to be kept separate.

For example, we can condition someone in the lab to a picture and a shock, and then present that picture without them being aware, right, so they're unconscious of the stimulus. The stimulus produces a response that we would call a fear response, but the person doesn't feel anything. He doesn't even know the stimulus is there. Fear is not what's driving those responses.

Charvy Narain: Do you think these two things are separable in the brain as well?

Dr. LeDoux: They're absolutely separable.

Charvy Narain: Would you talk about some of the work that shows they are separable?

Dr. LeDoux: They're separable because we can separate them in people. And if we don't need conscious fear to explain how threat detection and responding works in a person, we certainly don't need it in a rat. The idea is to understand the stuff that's relevant in rats and people that's the same across species, rather than start by bringing human fear into the rat to explain the human fear. If we want to study human fear, we have to study that.

Charvy Narain: You previously talked about the role of the amygdala in what I guess you'd now say is threat detection. So where is the fear center?

Dr. LeDoux: There's a growing movement in psychology called construction theory of emotion, and I've been a constructionist since the late 1970s when I worked on split brain patients. I've always interpreted fear as the conscious putting together of all of the stuff coming up underneath the hood into a feeling. People like Lisa Feldman Barrett, Jim Russell, and a bunch of others are talking about conscious fear now in this way, as a social or cognitive construction on the basis of unconscious information.

I think fear emerges in cortex, specifically in working memory and attention circuits. If you're not aware of it, you're not feeling it. You have to be aware of something to feel it. You can't have an unconscious feeling, I would say. And to be conscious of something, say a snake, and that you are in danger of being harmed by that snake, the snake and memories about what snakes are and even about what fear is have to be represented in working memory. Otherwise, you can't know that you are in danger.

Charvy Narain: So fear is a conscious percept?

Dr. LeDoux: Right. Exactly.

Charvy Narain: There's no such thing as an unconscious feeling of fear. I'm sure you know that there would be many people who would sort of disagree with this idea.
Dr. LeDoux: Most people don't disagree with it in principle, but they're reluctant to change because it's hard to change things.

Charvy Narain: What is the sort of work that would separate out these two things?

Dr. LeDoux: We don't need to do any more work to separate them. It's obvious that they're separable from the research we have now. Anxious will reveal all this. I wrote a paper in $P N A S$ recently called "Coming to terms with fear," where it's all explained as well.

I'm not doing any research to really test this, because I think it's pretty clear. As I said, most people agree that this is right, but they don't want to change because it's just too much trouble.

Charvy Narain: This idea that what a lot of people call fear is actually not, how does this change things?

Dr. LeDoux: Our research is paid for by public funding. If we tell the public that the amygdala is feeling fear, they're getting the wrong impression.

For example, there was a big splash about a finding that fear could be induced in a woman without an amygdala. But the only reason you'd be surprised that you could have fear in the absence of the amygdala is if you believed when you turned on the amygdala you got the feeling of fear. That leads to interpretations about the role of the amygdala in PTSD or panic disorder. The assumption is feelings of panic and fear and anxiety come from the amygdala. But if that's not true, and I don't think it is, we miss the opportunity to really understand where the awful feelings come from in these people.

The amygdala, when turned on, activates certain behaviors and releases stress hormones. It activates a lot of body systems. It triggers brain arousal. It focuses attention on the threat. It does a lot of stuff that ultimately contributes to the feeling of fear, but is not the feeling of fear.

Fear is not in the amygdala. Fear is a consequence. It's like you've got a lot of ingredients that are nonemotional ingredients that when put together allows the cognitive brain to make the feeling of fear.

Charvy Narain: So fear is a sort of emergent property of the brain?

Dr. LeDoux: You could say that.

Charvy Narain: How would you recontextualize the patients who have got things like PTSD? Or you talked about cognitive behavioral therapy. What sort of implications does this way of thinking have for those things?

Dr. LeDoux: That if you put too much cognition into the process of trying change behavior through extinction, you're putting competing systems at work.

You need to isolate the extinction process to weaken those bonds so that the stimulus is not going to produce the behavioral and physiological responses, and once 
you've done that, then you can address the cognitive component. I think if you put it all together, you're dealing with systems that should be separated.

Charvy Narain: What are you planning for the future?

Dr. LeDoux: The stuff we've been doing for all these years in rats are defensive reactions. You've got a tone, a shock; the tone elicits the reaction automatically. Now we're looking at how the brain acts in the face of danger. We are exploring different ways that the same stimulus, a tone that's been paired with a shock, can have a variety of other consequences that affect instrumental behaviors, the behaviors that are motivated by some goal. But all of this, the reactions and the actions, are implicit, under the hood, defensive activities. Conscious fear is a different matter. 


\section{$\$_{\text {CSH }}^{\infty}$ Cold Spring Harbor Symposia SYMPOSIA On Quantitative Biology}

\section{A Conversation with Joseph LeDoux}

Cold Spring Harb Symp Quant Biol 2014 79: 279-281

Access the most recent version at doi:10.1101/sqb.2014.79.12

\section{License}

Email Alerting Receive free email alerts when new articles cite this article - sign up in Service the box at the top right corner of the article or click here. 